\title{
EVALUASI REVITALISASI SISTEM ALARM KEBAKARAN PUSAT REAKTOR SERBA GUNA (PRSG)
}

\section{EVALUATION OF FIRE ALARM SYSTEM REVITALIZATION AT THE CENTER FOR MULTIPURPOSE REAKTOR}

\author{
Ranji Gusman ${ }^{1}$, Heri Suherkiman ${ }^{2}$, Sujarwono ${ }^{3}$, Sukino ${ }^{4}$ \\ 1,2,3,4 PRSG - BATAN Kawasan Puspiptek Gd. 31 Serpong, 15310 \\ email: ranjigusman@batan.go.id
}

Diterima : 24 Pebruari 2020, diperbaiki : 11 Maret 2020, disetujui : 13 April 2020

\begin{abstract}
ABSTRAK
EVALUASI REVITALISASI SISTEM ALARM KEBAKARAN PUSAT REAKTOR SERBA GUNA. Sistem alarm kebakaran merupakan salah satu bagian dari sistem instrumentasi dan kendali di PRSG. Setelah digunakan lebih dari 30 tahun, sistem ini banyak mengalami gangguan berupa seringnya muncul alarm palsu (false alarm). Disamping itu beberapa sensor telah mengalami kerusakan sehingga tidak dapat mendeteksi apabila terjadi kejadian kebakaran di PRSG. Sistem alarm kebakaran yang lama masih menggunakan sensor yang terdapat zat radioaktif berupa Amerisium (Am-241) untuk mendeteksi asap yang secara aturan internasional telah dilarang penggunaannya. Seiring dengan perkembangan teknologi, sistem baru yang dipasang dapat dilakukan pemrograman sehingga dapat memudahkan teknisi dalam melakukan perawatan dan membantu operator dalam mendeteksi kebakaran karena dilengkapi dengan tampilan Human Machine Interface (HMI). Karena alasan tersebut, maka sistem alarm kebakaran ini perlu dilakukan revitalisasi agar sistem dapat bekerja secara baik dalam mendeteksi kebakaran. Sistem ini terdiri dari 4 jenis sensor yaitu sensor aktif berupa sensor asap dan suhu, sensor asap berupa kamera, sensor pasif berupa kotak alarm manual (manual call point), dan sensor jalur alarm (alarm line). Keempat jenis sensor ini dipasang mengelilingi jalur alarm kebakaran seluruh gedung di PRSG dan mengirim sinyal ke panel kendali alarm kebakaran kemudian alarm tersebut ditampilkan pada panel tegak di Ruang Kendali Utama (RKU). Metode revitalisasi dilakukan dengan mempelajari sistem yang lama, melakukan pengumpulan data Input/Output (I/O), instalasi sistem dengan mengganti seluruh komponen dari sistem yang lama, pembuatan program, dan pembuatan tampilan HMI. Dari hasil evaluasi revitalisasi sistem alarm kebakaran yang baru dapat bekerja dengan baik dalam mendeteksi kebakaran di PRSG dan diharapkan dapat memudahkan operator dan petugas pengamanan dalam menemukan titik dimana kebakaran terjadi dengan cepat.
\end{abstract}

Kata kunci: sistem deteksi kebakaran, sensor pasif, sensor aktif, HMI

\section{ABSTRACT}

EVALUATION OF FIRE ALARM SYSTEM REVITALIZATION AT THE CENTER FOR MULTIPURPOSE REAKTOR. Fire alarm system is one of instrumentation and control system at the PRSG. After more than 30 years of used, system had a lot of trouble such as give false alarm to controller. Many sensors had broken that causes cannot detect if case of fire happened. The current system, still used Amerisium (Am-241) radioactive materials sensor to detect smoke which is in international regulation have been banned. Along the development of technology, a new programmable fire alarm system completed with Human Machine Interface (HMI) system can be installed. Because of that reason, the old fire alarm system at the PRSG must be revitalized. A new system consists of four type of sensors which are smoke and temperature sensors, fire camera sensors, manual call point, and alarm line sensors. All of sensors installed throughout 
PRSG building and give alarm signal to controller and display it in Main Control Room (MCR) if cause of fire happened. Revitalization methods are study literature, I/O collection data, installation, programming, and develop the HMI. Based on the result of evaluation, new fire alarm system at the PRSG can work properly and hopefully it can help operators and security officers to find the place if cause of fire happened quickly.

Key words: fire detection system, passive sensor, active sensor, HMI

\section{PENDAHULUAN}

Zu usat Reaktor Serba Guna (PRSG) adalah salah satu pusat di BATAN yang memiliki kewenangan dalam melakukan pemanfaatan Reaktor Serba Guna G.A Siwabessy (RSG-GAS). Seperti diketahui, aspek keselamatan di suatu reaktor nuklir amat sangat diperhatikan dikarenakan dampak sosial dan ekonomi yang timbul apabila suatu reaktor mengalami kecelakaan atau gangguan sangatlah besar. Salah satu gangguan yang perlu diperhatikan adalah kejadian kebakaran yang mungkin timbul di gedung reaktor maupun di gedung penunjang sekitar reaktor. Oleh karena itu sangat penting untuk PRSG memiliki sistem alarm kebakaran yang baik dan cepat dalam mendeteksi apabila kejadian kebakaran terjadi. Tugas dari sistem alarm kebakaran otomatis di PRSG adalah mendeteksi kebakaran oleh tipe detektor berbeda dan memproses sinyal detektor kemudian menampilkannya di panel tegak Ruang Kendali Utama (RKU) [1]. Sistem alarm kebakaran di PRSG yang selama ini digunakan terdiri dari 3 jenis sensor yaitu sensor aktif berupa sensor asap yang sensitif dengan waktu tanggap pendek dan dapat digunakan untuk uap dan gas yang masih menggunakan zat radioaktif berupa Amerisium (Am-241), sensor pasif berupa kotak alarm manual (manual call point) yang dipasang pada dinding dekat pintu di beberapa ruangan dan sensor jalur alarm (alarm line) yang dipasang pada lorong jalur kabel.

Ketiga jenis detektor ini dipasang mengelilingi jalur alarm kebakaran kemudian dalam kasus alarm kebakaran detektor akan mengirim sinyal kejadian kebakaran ke panel kendali alarm kebakaran. Pada panel akan muncul alarm lampu dan alarm suara kemudian memberikan sinyal alarm kebakaran ke Ruang Kendali Utama. Pada tahun 2018, banyak sensor sudah tidak dapat mendeteksi asap kebakaran saat dilakukan simulasi dan juga sering memberikan sinyal alarm kebakaran palsu (false alarm). Selain itu banyak modul pengolah sinyal yang sudah tidak berfungsi sehingga apabila terjadi kebakaran sesungguhnya, maka sistem tidak akan memberikan peringatan ke RKU. Seiring dengan perkembangan teknologi pada sistem alarm kebakaran, sensor asap yang menggunakan zat radioaktif sudah ditinggalkan dan beralih pada sensor yang menggunakan prinsip optik yang dapat mendeteksi asap, suhu, dan api. Selain itu, komponen-komponen pada sistem alarm kebakaran saat ini sudah memiliki alamat yang melekat pada perangkat (addressable) sehingga dapat dengan mudah dilakukan pemrograman dan pembuatan tampilan HMI yang membantu teknisi dalam melakukan perawatan dan membantu operator dalam menemukan kejadian kebakaran. Dengan kondisi tersebut, maka diperlukan suatu revitalisasi sistem alarm kebakaran di PRSG untuk menggantikan sistem lama. Kegiatan revitalisasi sistem alarm kebakaran ini dilakukan dalam beberapa tahapan meliputi tahapan mempelajari sistem yang lama, melakukan pengumpulan data Input/Output (I/O), instalasi sistem dengan mengganti seluruh kom- 
ponen dari sistem yang lama, pembuatan program, pembuatan tampilan HMI dan kegiatan evaluasi untuk memastikan sistem baru bekerja dengan baik. Pada tampilan $\mathrm{HMI}$ terdapat denah lokasi seluruh gedung di PRSG dan sensorsensor alarm kebakaran yang terpasang. Sehingga apabila terjadi kebakaran, maka akan terdapat suatu tanda berupa blink pada sensor yang mendeteksi kejadian kebakarn.

Tahun 2017, Rika Sri Rizky melakukan penelitian pembuatan sistem alarm kebakaran pada gedung menggunakan PLC Omron sebagai pemroses sinyal sensor [2]. Pada penelitian tersebut hanya menggunakan sensor asap untuk mendeteksi kebakaran dan belum terdapat tampilan HMI. Tahun 2017, Khaerul Ikhfan melakukan penelitian pembuatan sistem monitoring alarm kebakaran dengan menggunakan sensor suhu [3]. Pada penelitian ini digunakan pemroses berupa Arduino Uno dan terdapat tampilan menggunakan bahasa pemrograman C Sharp. Perbedaan penelitian revitalisasi sistem alarm kebakaran di PRSG dengan penelitianpenelitian yang sudah ada sebelumnya adalah sensor yang digunakan untuk mendeteksi kebakaran di PRSG terdiri dari 4 sensor yaitu sensor asap, suhu, kotak alarm manual (manual call point), dan alarm line. Sensor asap dan suhu menggunakan sensor produk Siemens Cerberus multisensor smoke detector tipe $\mathrm{OOH} 740$ yang dapat difungsikan sebagai sensor asap, sensor suhu, atau keduanya. Selain itu digunakan juga sensor asap menggunakan fire camera keluaran OSID Instrument. Untuk bagian pemrosesnya digunakan panel kendali produk Siemens Cerberus tipe FC726-ZA yang dapat diprogram untuk dilakukan pengaturan dengan menggunakan perangkat lunak Siemens Cerberus FXS7212 dan dihubungkan ke perangkat lunak Desigo CC sebagai penampil HMI.

\section{LANDASAN TEORI}

\section{Sistem Alarm Kebakaran PRSG}

Sistem alarm kebakaran adalah seperangkat peralatan yang terdiri dari sensor/detektor dan unit kendali yang terpasang pada titik-titik strategis dengan jenis deteksi yang berbeda (sesuai dengan kondisi lapangan) pada sebuah gedung dengan maksud melakukan pendeteksian dini sebelum terjadi kebakaran yang lebih besar sehingga bahaya kebakaran dapat ditanggulangi atau diminimalisir untuk mengamankan dan menyelamatkna jiwa, harta benda dan kelangsungan fungsi bangunan [4]. Mulai saat pembangunan reaktor RSGGAS hingga tahun 2018, sistem alarm kebakaran di PRSG hanya meliputi di gedung reaktor, gedung bantu, gedung gudang induk, gedung pendingin sekunder dan gedung diesel. Pada gedung administrasi perkantoran PRSG dan gedung penyimpanan bahan kimia dan oli belum terdapat sistem alarm kebakaran. Sehingga pada revitalisasi dilakukan penambahan sistem alarm kebakaran pada gedung-gedung tersebut. Sistem alarm terdiri dari sensorsensor yang mendeteksi terjadinya kebakaran, kemudian sinyal keluaran sensor tersebut dikirim ke panel kendali untuk diproses dan akan mengeluarkan output berupa alarm apabila terjadi kebakaran dan juga sebagai tanda kegagalan pada sistem. Teknologi sistem alarm kebakaran pada revitalisasi ini menggunakan:

- Fire alarm control panel Siemens FC726-ZA tipe modular dengan topologi loop tertutup.

- Detektor kebakaran Siemens OOH740 tipe addressable dengan fungsi deteksi asap dan panas.

- Linier heat detection cable (alarm line) tipe TC155N. 
- Manual call point Siemens FDM226 IP65 yang dipasang pada ketinggian 1,5 meter dari lantai.

- Operating Voltage 24 VDC.

- Ketinggian area diatas 12meter menggunakan fire camera OSID-90 $\left(80^{\circ}\right.$ radius pendeteksian).

- Kabel sinyal menggunakan 18 AWG, 1 pair, kabel power menggunakan jenis NYY multicore diameter $1,5 \mathrm{~mm}^{2}$.

- Alarm akustik/bel dipasang 0,5meter dibawah plafon.

- Semua peralatan sistem alarm kebakaran di grounding dengan hambatan maksimum $0,2 \mathrm{ohm}$ sesuai dengan grounding bangunan PRSG.

Aturan penggunaan teknologi revitalisasi dan instalasi sistem alarm kebakaran di PRSG ini selain mengikuti standar yang lama, juga mengikuti Standar Nasional Indonesia SNI No. 031736-2000 tentang tata cara perencanaan sistem proteksi pasif untuk pencegahan bahaya kebakaran pada bangunan rumah dan gedung, serta SNI No. 03-3985-2000 tentang tata cara perencanaan, pemasangan dan pengujian sistem proteksi pasif untuk pencegahan bahaya kebakaran pada bangunan gedung.

\section{Panel Kendali Sistem Alarm Kebakaran Siemens Cerberus FC726-ZA}

Panel kendali sistem alarm kebakaran Siemens Cerberus FC726-ZA adalah unit kendali sistem alarm kebakaran produk Siemens yang ditempatkan diruang kendali. Unit ini terdiri dari modul I/O dari dan ke peralatan yang diperlukan untuk pemantauan, indikasi alarm/fault, pensinyalan dan kendali sistem alarm kebakaran [5]. Panel ini dapat dilakukan pemrograman dengan memasukkan setiap komponen I/O sehingga apabila terjadi kebakaran memudahkan dalam mengidentifikasi lokasi kejadian. Adapun diagram alir dari proses identifikasinya adalah sebagai berikut.

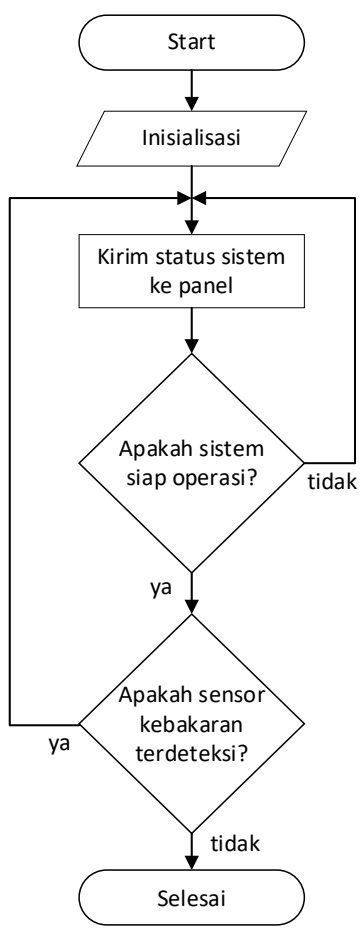

Gambar 1. Diagram alir identifikasi kebakaran.

Pada panel ini juga terdapat panel operasi yang terdiri dari elemen-elemen operasi, akustik dan indikasi. Elemen indikasi dan akustik menginformasikan operator mengenai status sistem (alarm, fault, mode operasi dan sebagainya).

\section{Sensor-Sensor Sistem Alarm Kebakaran.}

Sistem alarm kebakaran di PRSG terdiri dari beberapa jenis sensor yang berfungsi untuk mendeteksi terjadinya kebakaran, yaitu:

1. Siemens Cerberus multisensor smoke detector tipe $\mathrm{OOH} 740$

Sensor ini bekerja menggunakan prinsip optik yang berfungsi mendeteksi asap dan suhu akibat kebakaran [6]. Pada penggunaannya 
sensor ini dapat difungsikan sebagai sensor asap atau suhu saja, atau difungsikan keduanya. Sensor ini memiliki alamat (addressable) sehingga dapat dilakukan pengaturan untuk penamaan dan sensitivitasnya melalui perangkat lunak Siemens Cerberus FXS7212.

2. OSID fire camera

Sensor ini terdiri atas kamera pemancar sinar infra merah yang kemudian sinar tersebut ditangkap oleh perangkat penerima [7]. Apabila terjadi kebakaran dan asap dari kebakaran tersebut menghalangi sinar pancaran, maka bagian penerima akan mengirimkan sinyal kebakaran dan kemudian diolah oleh panel kendali. Berbeda dengan sensor asap dan suhu sebelumnya, sensor ini tidak memiliki alamat (unaddressable) sehingga untuk dapat diatur penamaan maka diperlukan modul I/O untuk mengidentifikasi sinyal dari sensor ini.

3. Sensor jalur alarm (alarm line) tipe TC $155 \mathrm{~N}$

Sensor jalur alarm (alarm line) ini dikenal juga dengan sebutan linier heat detection cable. Sensor ini merupakan sensor panas yang berbentuk menyerupai kabel dengan 2 buah inti (core) yang dibungkus dengan suatu bahan isolasi [8]. Apabila terkena panas, bahan isolasi akan meleleh dan menyebabkan kedua inti (core) dari kabel tersebut menjadi hubung singkat (short circuit). Sama seperti OSID fire camera, sensor ini tidak memiliki alamat (unaddressable) sehingga diperlukan I/O tambahan untuk mendeteksi sinyal keluarannya.

4. Kotak alarm manual (manual call point)

Sensor kotak alarm manual (manual call point) merupakan sensor pasif berupa switch yang apabila terjadi kebakaran, maka orang yang melihat pertama kali kejadian kebakaran tersebut dapat memecahkan kaca pada sensor tersebut dan menekan switch yang terdapat di dalam kotak. Sensor ini memiliki alamat (addressable) sehingga dapat dilakukan pemrograman penamaan sehingga lebih cepat dideteksi apabila terjadi kebakaran. Sensor ini dipasang pada dinding dekat pintu di beberapa ruangan di PRSG.

\section{Perangkat Lunak Siemens Cerberus FXS7212}

Perangkat lunak Siemens Cerberus FXS7212 merupakan perangkat lunak produk Siemens yang terinstal pada komputer server sistem alarm kebakaran berfungsi untuk melakukan pemrograman dari sistem alarm kebakaran dengan panel kendali Siemens Cerberus FC726. Perangkat lunak ini digunakan untuk mengatur kerja dari seluruh $\mathrm{I} / \mathrm{O}$ yang digunakan seperti pengalamatan dan penamaan sensor, sensitivitas sensor, mendeteksi sensor dan urutan penempatan sesnsor, serta untuk mengatur komunikasi antara panel kendali dan komputer.

\section{Perangkat Lunak Desigo CC SMC dan Desigo CC}

Perangkat lunak Desigo CC SMC (System Management Console) merupakan perangkat lunak keluaran Siemens yang digunakan untuk mengatur data dari panel kendali sistem alarm kebakaran dan mendistibusikan data tersebut ke beberapa komputer client yang terpasang. Pada sistem alarm kebakaran di PRSG, terdiri dari tiga buah komputer yaitu satu sebagai server dan dua sebagai client. Perangkat lunak ini mengatur data antara komputer server dan client. Sedangkan perangkat lunak Desigo CC merupakan perangkat lunak yang digunakan untuk membuat tampilan HMI dari sistem alarm 
kebakaran sehingga operator dapat lebih mudah dalam mendeteksi apabila terjadi kebakaran.

\section{METODOLOGI}

Tahapan revitalisasi sistem dimulai dengan melakukan studi literatur dengan mempelajari sistem dan mengumpulkan data I/O baik untuk sistem yang lama dan penambahan sistem baru di gedung administrasi perkantoran PRSG, gedung gudang kimia dan gudang oli. Kemudian dilakukan pembongkaran sistem lama yang terpasang dan memasang sistem alarm kebakaran yang baru. Selanjutnya melakukan pemrograman panel kendali dan pengaturan komunikasi melalui perangkat lunak Siemens Cerberus FXS7212 dan Desigo CC SMC. Setelah itu dilakukan pemrograman pembuatan tampilan HMI menggunakan perangkat lunak Desigo CC dan langkah terakhir adalah uji fungsi dan komisioning.

\section{Studi literatur}

Pada tahap ini, dilakukan pendalaman materi mengenai sistem lama dan menemukan beberapa kelemahan sistem lama untuk dijadikan perbaikan pada sistem yang baru. Selain itu juga dilakukan pembuatan desain baru sistem alarm kebakaran di reaktor RSG-GAS mengenai aturan yang dipakai sebagai acuan, pemilihan teknologi, jenis dan tipe detektor sistem alarm kebakaran yang digunakan, area yang di proteksi, desain instalasi umum dan topologi jaringan.

2. Pembongkaran sistem lama dan instalasi sistem baru

Setelah semua data pada tahap studi literatur didapat, selanjutnya kegiatan instalasi sistem baru dimulai. Sebelum instalasi dimulai, dilakukan pembongkaran panel kendali dan juga sensor lama yang terpasang. Setelah sistem lama terbongkar, maka selanjutnya dilakukan instalasi sistem baru. Instalasi dilakukan mengikuti sesuai ketentuan desain dan aturan yang telah dipelajari pada kegiatan studi literatur. Kegiatan instalasi sistem baru meliputi instalasi panel kendali, intalasi sensor-sensor alarm kebakaran, dan instalasi kabel jaringan pada personal komputer. Adapun blok diagram dari sistem alarm kebakaran baru yang akan dipasang adalah sebagai berikut.

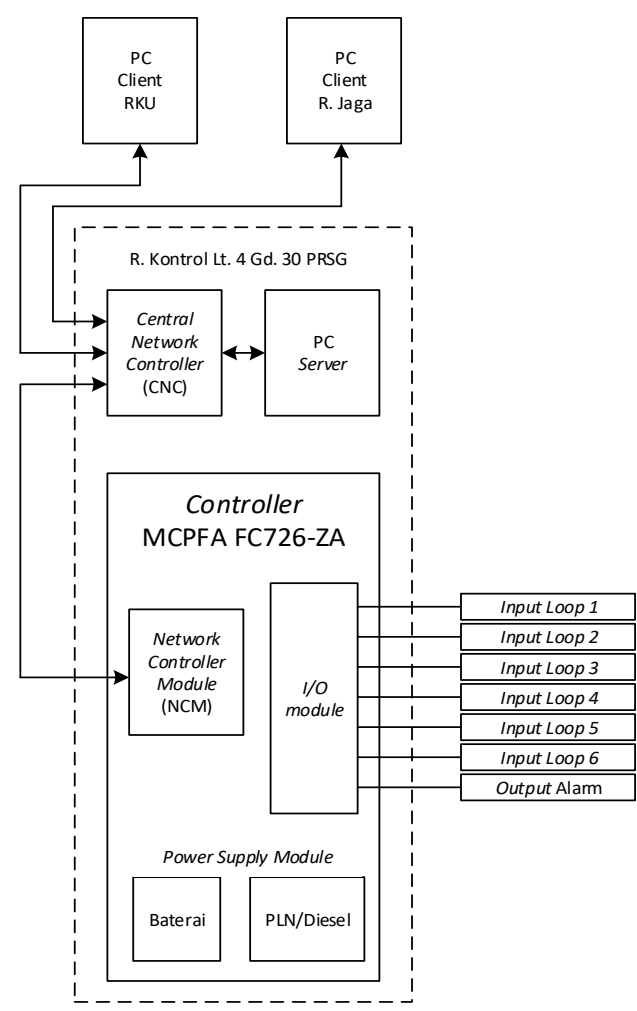

Gambar 2. Blok diagram sistem alarm kebakaran baru.

Pada Gambar 2 dapat dilihat bahwa sistem alarm kebakaran baru yang akan dipasang di PRSG memiliki kontroler yang dapat diprogram untuk mengatur seluruh komponen sistem mulai dari masukan berupa sensor-sensor yang terbagi dalam 6 loop (akan dijelaskan pada bab selanjutnya) hingga keluaran berupa 
alarm. Selain itu kontroler ini juga memiliki Network Controller Module (NCM) untuk melakukan komunikasi dengan Personal Computer (PC) sehingga sistem dapat ditampilkan berupa HMI. Pada sistem alarm kebakaran dilengkapi dengan power supply module yang berasal dari listrik PLN atau pembangkit darurat dan baterai. Hal ini sesuai dengan prosedur yang digunakan [9].

3. Pemrograman panel kendali dan pengaturan komunikasi

Setelah seluruh kegiatan instalasi sistem baru selesai, maka diperlukan pengetesan jalur sensor menggunakan line tester untuk memastikan jalur terkoneksi dengan baik. Apabila koneksi jalur sudah baik dari hasil line tester, maka pemrograman dapat dimulai. Apabila masih terdapat koneksi yang tidak benar, maka perlu dilakukan perbaikan. Pemrograman panel kendali sistem alarm kebakaran menggunakan perangkat lunak Siemens Cerberus FXS7212. Pada perangkat lunak ini dilakukan penarikan seluruh data sensor yang masuk ke modul I/O panel kendali, pengaturan seluruh sensor alarm kebakaran mulai dari sensor asap dan suhu, sensor kotak alarm manual (manual call point), sensor jalur alarm (alarm line), dan sensor kamera asap. Semua jalur sensor tersebut dibagi menjadi 6 loop jalur kabel. Pada masingmasing loop, setiap sensor memiliki alamat tertentu (addressable) sehingga dapat dilakukan penamaan untuk mempermudah identifikasi saat sensor tersebut aktif mendeteksi kebakaran. Setelah pemrograman panel selesai, dilakukan pengaturan komunikasi antar personal komputer (server dan client) sistem alarm kebakaran menggunakan perangkat lunak Desigo CC SMC.

\section{Pembuatan tampilan HMI}

Pada pembuatan tampilan $\mathrm{HMI}$ digunakan perangkat lunak Desigo CC, tampilan $\mathrm{HMI}$ terdiri dari bagian utama (home) yang dibagi menjadi 6 (enam) kelompok yang mewakili gedung-gedung di PRSG yaitu, gedung administrasi dan gedung reaktor (gedung 30 dan 31 ), gedung pompa sekunder (gedung 32), gedung menara pendingin (gedung 33 ), gedung gudang induk (gedung 34 ), gedung RKD (gedung 35), dan gedung gudang kimia dan oli (gedung 36 ). Dari enam kelompok tersebut, dibagi-bagi kembali menjadi sub-sub kelompok yang mewakili tiap lantai dari masing-masing gedung tersebut. Pada pembuatan tampilan HMI, apabila terjadi kebakaran maka akan terdapat tanda berwarna merah kedip-kedip (blink) yang akan memudahkan operator dalam mendeteksi kebakaran di PRSG.

\section{Komisioning}

Tahapan terakhir dalam revitalisasi sistem alarm kebakaran di PRSG adalah dilakukan komisioning. Kegiatan komisioning dilakukan dengan menguji koneksi dan kerja dari setiap sensor yang terpasang mulai dari sensor deteksi asap dan suhu, sensor fire camera, sensor jalur alarm, dan kotak alarm manual. Untuk pengujian koneksi seluruh sensor dilakukan dengan menggunakan line tester melalui perangkat keras dan melalui fasilitas yang tersedia pada perangkat lunak Siemens Cerberus FXS7212. Adapun kegiatan komisioning dapat dilihat pada Gambar 3. Untuk pengujian kerja sensor dilakukan dengan melakukan simulasi, untuk sensor deteksi asap dan suhu, simulasi menggunakan gas khusus sebagai pengganti asap kebakaran dan pemanas (Gambar 3a). Pada sensor fire camera digunakan simulator berupa plastik mika merah untuk menghalangi pancaran sinar infra merah dari pemancar (Gambar 3b). Pada sensor jalur alarm dilakukan simulasi berupa membakar kabel hingga bahan isolasi pada sensor meleleh dan 
memberikan sinyal alarm kebakaran (Gambar 3c). Untuk kotak alarm kebakaran dilakukan simulasi dengan menggunakan kunci seolah-olah sakelar pada kotak alarm tertekan hingga memberikan sinyal alarm (Gambar 3d).

\section{Evaluasi Revitalisasi}

Tahapan terakhir dalam kegiatan revitalisasi sitem alarm kebakaran di PRSG adalah kegiatan evaluasi. Evaluasi dilakukan dengan membandingkan hasil

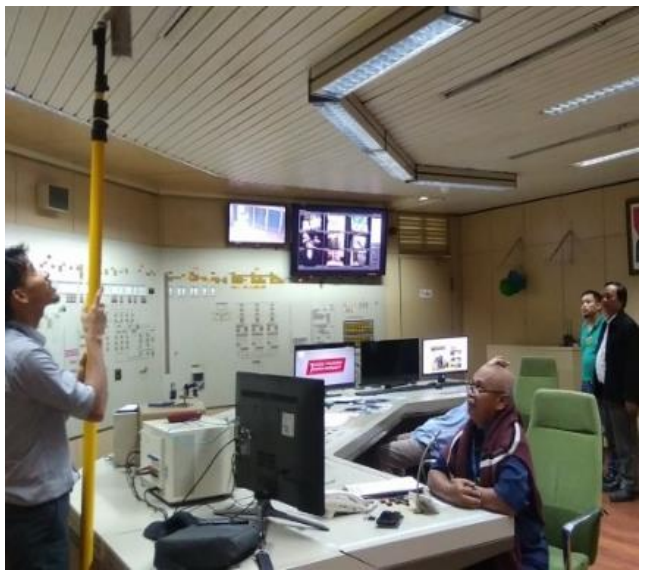

(a)

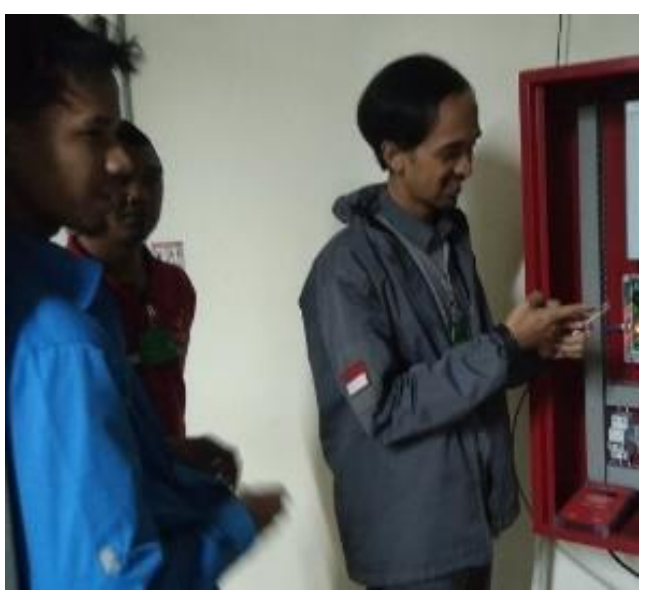

(c) dari setiap tahapan dengan standar yang digunakan. Evaluasi dilakukan mulai dari tahap studi literatur hingga komisioning.

\section{HASIL DAN PEMBAHASAN}

Berdasarkan tahapan kegiatan revitalisasi yang telah dilakukan, adapun hasil dan pembahasan yang diperoleh adalah sebagai berikut:

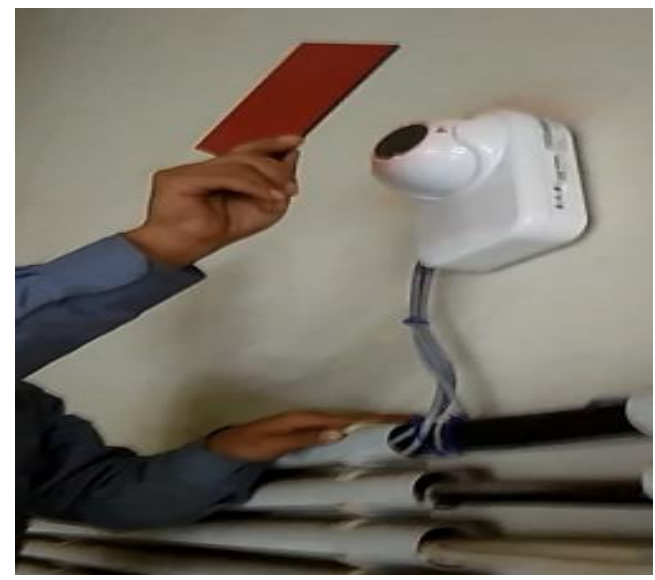

(b)

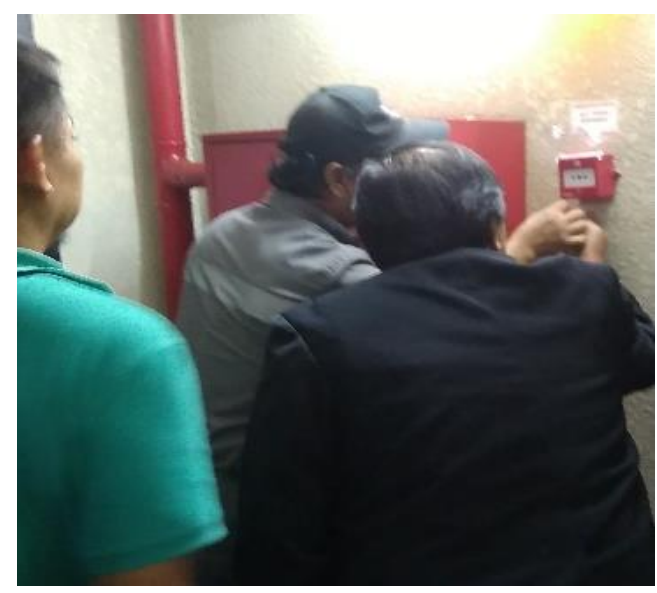

(d)

Gambar 3. Komisioning. 
1. Hasil pembongkaran sistem lama dan instalasi sistem baru

Pembongkaran sistem lama dihasilkan sensor asap dan kotak alarm manual yang selanjutnya dilimbahkan dan ditangani oleh petugas proteksi radiasi
PRSG dikarenakan sensor masih menggunakan zat radioaktif pemancar alpha (Amerisium). Untuk sistem baru yang terpasang, adapun jumlahnya adalah ditunjukkan pada Tabel 1.

Tabel 1. Komponen sistem alarm kebakaran terpasang.

\begin{tabular}{|c|c|c|c|c|c|c|c|}
\hline Komponen & Loop 1 & Loop 2 & Loop 3 & Loop 4 & Loop 5 & Loop 6 & Total \\
\hline $\begin{array}{l}\text { Siemens Cerberus } \\
\text { multisensor smoke detector } \\
\text { tipe } \mathrm{OOH} 740\end{array}$ & 87 & 65 & 87 & - & 65 & 73 & 377 buah \\
\hline OSID fire camera $(\mathrm{I} / \mathrm{O})$ & - & - & - & - & - & 6 & 6 buah \\
\hline $\begin{array}{l}\text { Sensor jalur alarm (alarm } \\
\text { line) tipe TC } 155 \mathrm{~N}(\mathrm{I} / \mathrm{O})\end{array}$ & - & - & - & 15 & - & - & 15 buah \\
\hline $\begin{array}{l}\text { Kotak alarm manual (manual } \\
\text { call point) }\end{array}$ & 14 & 4 & 6 & - & 5 & 7 & 36 buah \\
\hline Modul I/O & 2 & 1 & 3 & 0 & 2 & 3 & 11 buah \\
\hline $\begin{array}{l}\text { Panel kendali sistem alarm } \\
\text { kebakaran Siemens } \\
\text { Cerberus FC726 }\end{array}$ & - & - & - & - & - & - & 1 buah \\
\hline PC server & - & - & - & - & - & - & 1buah \\
\hline PC client & - & - & - & - & - & - & 2 buah \\
\hline
\end{tabular}

2. Hasil pemrograman panel kendali dan pengaturan komunikasi

Sebelum dilakukan pemrograman, jalur instalasi sistem alarm kebakaran PRSG dilakukan pengujian dengan menggunakan line tester dengan perangkat lunak. Adapun hasil dari pengujian jalur seluruh sensor adalah seperti ditunjukkan pada Tabel 2.

Tabel 2. Hasil pengujian jalur sistem alarm kebakaran.

\begin{tabular}{lcccccc}
\hline \multicolumn{1}{c}{ Parameter } & Loop 1 & Loop 2 & Loop 3 & Loop 4 & Loop 5 & Loop 6 \\
\hline Number of devices & 103 & 70 & 96 & 15 & 72 & 89 \\
\hline Branches & 0 & 0 & 0 & 0 & 0 & 0 \\
\hline Line type & loop & loop & loop & loop & loop & loop \\
\hline Line current & n/a & n/a & n/a & n/a & n/a & n/a \\
\hline Leak current & n/a & n/a & n/a & n/a & n/a & n/a \\
\hline Loop resistance (+) & n/a & n/a & n/a & n/a & n/a & n/a \\
\hline Loop resistance (-) & n/a & n/a & n/a & n/a & n/a & n/a \\
\hline
\end{tabular}

Pada Tabel 2 dapat dilihat bahwa hasil pengujian jalur untuk setiap loop diperoleh hasil yang baik. Ini ditandai dengan tidak adanya percabangan (branches) yang terjadi. Selain itu jumlah sensor dan $\mathrm{I} / \mathrm{O}$ yang terdeteksi sama dengan jumlah yang terpasang. Untuk pengaturan koneksi komputer server dan komputer client digunakan perangkat lunak Desigo CC SMC. Koneksi antar komputer server dan client akan berhasil (baik) apabila terdapat tanda indikator hijau saat dijalankan (run). Adapun hasil dari pengaturan ini seperti pada Gambar 4. 


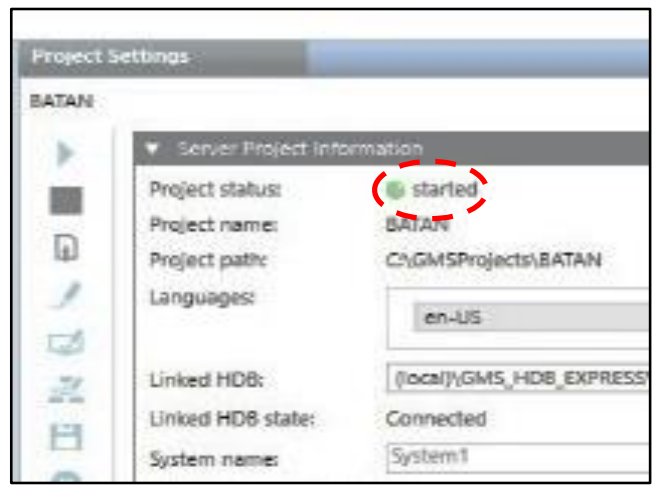

3. Hasil pembuatan tampilan $\mathrm{HMI}$

Hasil tampilan HMI dan contoh salah satu denah sistem alarm kebakaran PRSG ditunjukkan pada Gambar 5. Tampilan HMI sistem alarm kebakaran PRSG memiliki tampilan utama (home) yang menampilkan setiap gedunggedung di PRSG disertai dengan lantai dimana setiap sensor diletakkan.

Gambar 4. Hasil pengaturan koneksi komputer server dan client.

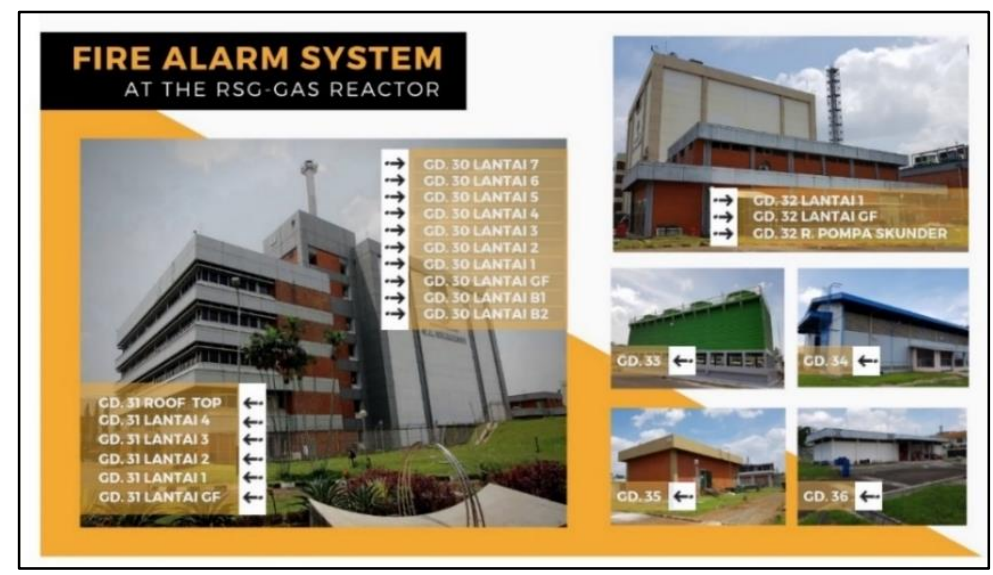

(a)

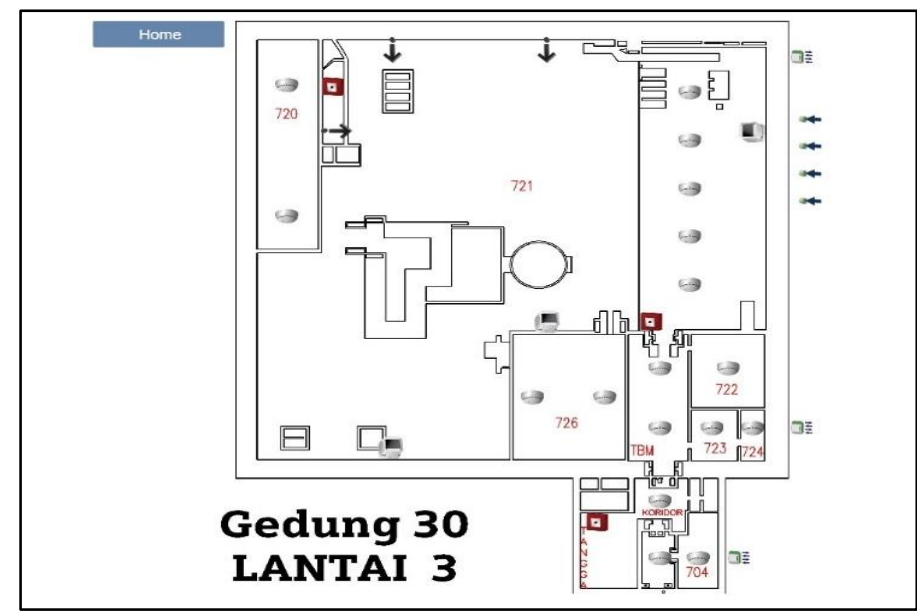

(b)

Gambar 5. (a) Tampilan halaman utama HMI,

(b) denah sistem alarm kebakaran PRSG. 
Apabila sistem mendeteksi

kebakaran, maka akan timbul tanda berupa blink pada tanda panah di tampilan home dan apabila dilakukan klik pada tanda tersebut akan menampilkan denah dan akan menunjukkan sensor mana yang medeteksi kebakaran berupa tanda blink pada sensor.

4. Hasil Komisioning

Kegiatan komisioning sistem alarm kebakaran PRSG terdiri dari komisioning jalur menggunakan line tester yang hasilnya seperti telah disajikan pada Tabel 2. Kemudian hasil komisioning dari sensor asap dan panas yang terpasang disajikan pada Tabel 3 sebagai berikut.

Tabel 3. Hasil komisioning Siemens Cerberus multisensor smoke detector tipe $\mathrm{OOH} 740$.

\begin{tabular}{cccc}
\hline \multirow{2}{*}{ Loop } & Jumlah & \multicolumn{2}{c}{ Hasil komisioning } \\
\cline { 3 - 4 } sensor & & $\begin{array}{c}\text { Saat } \\
\text { smoke } \\
\text { tester } \\
\text { diberikan }\end{array}$ & $\begin{array}{c}\text { Saat smoke } \\
\text { tester tidak } \\
\text { diberikan }\end{array}$ \\
\hline Loop 1 & 87 & Alarm & Tidak alarm \\
\hline Loop 2 & 65 & Alarm & Tidak alarm \\
\hline Loop 3 & 87 & Alarm & Tidak alarm \\
\hline Loop 4 & - & - & - \\
\hline Loop 5 & 65 & Alarm & Tidak alarm \\
\hline Loop 6 & 73 & Alarm & Tidak alarm \\
\hline
\end{tabular}

Pada Tabel 3 dapat dilihat bahwa untuk sensor pada setiap loop akan memberikan sinyal alarm kebakaran saat dilakukan simulasi dengan menggunakan smoke tester dan akan tertampil pada HMI di komputer server dan client. Selain sensor asap dan panas, komisioning juga dilakukan sensor asap yang metode deteksi menggunakan kamera (OSID fire camera) yang hasilnya disajikan pada Tabel 4.

\begin{tabular}{lcc} 
Tabel 4. Hasil komisioning OSID fire \\
& \multicolumn{2}{c}{ Hasil komisioning } \\
\cline { 2 - 3 } Sensor & $\begin{array}{c}\text { Saat } \\
\text { dihalangi } \\
\text { plastik } \\
\text { simulasi }\end{array}$ & $\begin{array}{c}\text { Saat tidak } \\
\text { dihalangi } \\
\text { plastik } \\
\text { simulasi }\end{array}$ \\
\hline Reactor hall 1 & Alarm & Tidak alarm \\
\hline Reactor hall 2 & Alarm & Tidak alarm \\
\hline Reactor hall 3 & Alarm & Tidak alarm \\
\hline Experiment hall 1 & Alarm & Tidak alarm \\
\hline Experiment hall 2 & Alarm & Tidak alarm \\
\hline Experiment hall 3 & Alarm & Tidak alarm \\
\hline
\end{tabular}

Pada Tabel 4, sensor fire camera akan memberikan sinyal alarm kebakaran saat dilakukan simulasi dengan menghalangi modul transmitternya dengan menggunakan plastik simulasi dan akan tertampil pada $\mathrm{HMI}$ di komputer server dan client. Selanjutnya komisioning juga dilakukan sensor jalur alarm (alarm line) yang hasilnya disajikan pada Tabel 5.

Tabel 5. Hasil komisioning sensor alarm line.

\begin{tabular}{lcc}
\hline \multirow{2}{*}{ Jalur } & \multicolumn{2}{c}{ Hasil komisioning } \\
\cline { 2 - 3 } & $\begin{array}{c}\text { Saat sensor } \\
\text { dibakar }\end{array}$ & $\begin{array}{c}\text { Saat sensor } \\
\text { tidak dibakar }\end{array}$ \\
\hline Jalur 1 & Alarm & Tidak alarm \\
\hline Jalur 2 & Alarm & Tidak alarm \\
\hline Jalur 3 & Alarm & Tidak alarm \\
\hline Jalur 4 & Alarm & Tidak alarm \\
\hline Jalur 5 & Alarm & Tidak alarm \\
\hline Jalur 6 & Alarm & Tidak alarm \\
\hline Jalur 7 & Alarm & Tidak alarm \\
\hline Jalur 8 & Alarm & Tidak alarm \\
\hline Jalur 9 & Alarm & Tidak alarm \\
\hline Jalur 10 & Alarm & Tidak alarm \\
\hline Jalur 11 & Alarm & Tidak alarm \\
\hline Jalur 12 & Alarm & Tidak alarm \\
\hline Jalur 12 & Alarm & Tidak alarm \\
\hline Jalur 14 & Alarm & Tidak alarm \\
\hline Jalur 15 & Alarm & Tidak alarm \\
\hline
\end{tabular}

Pada Tabel 5 dapat dilihat bahwa untuk sensor jalur alarm akan memberikan sinyal alarm kebakaran saat dilakukan simulasi dengan membakar sensor jalur alarm hingga isolasi pada sensor meleleh dan menyebabkan hubung singkat dan akan tertampil pada HMI di komputer server dan client. Komisioning 
juga dilakukan pada kotak alarm manual (manual call point) yang hasilnya disajikan pada Tabel 6.

Tabel 6. Hasil komisioning kotak alarm manual (manual call point).

\begin{tabular}{cccc}
\hline Loop & Jumlah & \multicolumn{2}{c}{ Hasil komisioning } \\
\cline { 3 - 4 } sensor & $\begin{array}{c}\text { Saat sensor } \\
\text { dimasukkan } \\
\text { kunci }\end{array}$ & $\begin{array}{c}\text { Saat } \\
\text { kunci } \\
\text { dicabut }\end{array}$ \\
\hline Loop 1 & 14 & Alarm & $\begin{array}{c}\text { Tidak } \\
\text { alarm }\end{array}$ \\
\hline Loop 2 & 4 & Alarm & $\begin{array}{c}\text { Tidak } \\
\text { alarm }\end{array}$ \\
\hline Loop 3 & 6 & Alarm & $\begin{array}{c}\text { Tidak } \\
\text { alarm }\end{array}$ \\
\hline Loop 4 & - & - & - \\
\hline Loop 5 & 5 & Alarm & $\begin{array}{c}\text { Tidak } \\
\text { alarm }\end{array}$ \\
\hline Loop 6 & 7 & Alarm & $\begin{array}{c}\text { Tidak } \\
\text { alarm }\end{array}$ \\
\hline
\end{tabular}

Pada Tabel 6, sensor kotak alarm manual (manual call point) akan memberikan sinyal alarm kebakaran saat dilakukan simulasi dengan memasukkan kunci pada kotak alarm seolah-olah saklar tertekan dan sinyal alarm kebakaran akan tertampil pada HMI di komputer server dan client.

\section{Hasil Evaluasi}

Berdasarkan evaluasi yang dilakukan, kegiatan instalasi telah memenuhi semua syarat dan mengikuti ketentuan dalam hasil studi literatur mengenai tata cara aturan pemasangan seluruh sensor-sensor dan pengkabelan dari sistem alarm kebakaran. Selanjutnya kegiatan evaluasi juga dilakukan pada tahapan pemograman dan komisioning. Pada tahap pemrograman, evaluasi dilakukan dengan metode trial dan error mengenai kaidah keselamatan dari sistem alarm kebakaran yang lama dan diimplementasikan pada sistem yang baru dalam bentuk program. Dalam kegiatan komisioning, evaluasi dilakukan dengan memastikan semua fungsi dari sistem alarm kebakaran telah berfungsi sesuai dengan prosedur yang digunakan dan semua fitur dari sistem yang lama dapat diimplementasikan dengan baik. Akan tetapi, kegiatan evaluasi juga berlanjut setelah tahap komisioning selesai, selama pengujian setelah komisioning terdapat beberapa sensor yang memberikan sinyal alarm kebakaran padahal tidak terjadi kebakaran (false alarm). Ini terjadi pada ruangan berdebu (seperti pada gudang induk, pada ruang kapasitor bank, ruang diesel dan ruang transformator), ruang yang memiliki uap panas (seperti pada dapur), dan ruang dengan asap rokok. Sehingga pada tahap evaluasi juga dilakukan pengaturan ulang sensitivitas sensor asap dan panas sehingga tidak menimbulkan alarm palsu. Adapun dari kegiatan evaluasi diperoleh perbandingan dari sistem lama dengan sistem baru yang disajikan pada Tabel 7 .

Tabel 7. Perbandingan sistem lama dan baru

\begin{tabular}{lll}
\hline \multicolumn{1}{c}{ Parameter } & Sistem lama & Sistem baru \\
\hline Kontroler & $\begin{array}{l}\text { Modul } \\
\text { Analog }\end{array}$ & Modul Digital \\
\hline Sensor Asap & Radioaktif & Optikal \\
\hline Pemrograman & Tidak ada & $\begin{array}{l}\text { Ada } \\
\text { (addressable) }\end{array}$ \\
\hline Jaringan & Analog & Digital (LAN) \\
\hline $\begin{array}{l}\text { Indikator } \\
\text { kebakaran }\end{array}$ & Lampu & HMI (PC) \\
indikator & \\
\hline
\end{tabular}

Pada Tabel 7 dapat dilihat perbandingan antara sistem lama dan baru, dari hasil evaluasi yang telah dilakukan, maka sistem yang baru dapat menggantikan sistem yang lama dengan kinerja yang lebih baik. Hal ini dikarenakan sistem baru telah memiliki teknologi digital melalui jaringan LAN dan dilengkapi pemrograman sehingga dalam perbaikan dan indentifikasi kebakaran dapat lebih mudah dan cepat. Selain itu, sistem baru dilengkapi dengan HMI berupa tampilan denah dari setiap sensor yang terpasang sehingga memudahkan operator dalam menemukan kejadian kebakaran di PRSG. 


\section{KESIMPULAN}

Revitalisasi sistem alarm kebakaran di PRSG telah berhasil dilakukan. Dari hasil evaluasi revitalisasi, sistem alarm kebakaran PRSG mengalami penambahan sensor yaitu pada gedung administrasi PRSG dan gedung gudang kimia dan oli. Sensor-sensor yang digunakan pada sistem alarm kebakaran terdiri atas sensor asap dan panas, sensor asap dengan kamera (OSID fire camera), sensor jalur alarm, dan sensor kotak alarm manual. Sensor-sensor tesebut telah bekerja dengan baik dan akan memberikan sinyal alarm kebakaran ke tampilan HMI pada komputer server dan client yang ada di RKU, ruang kendali alarm kebakaran, dan ruang Unit Pengamanan Nuklir (UPN) PRSG. Dari hsil revitalisasi diharapkan sistem yang baru dapat meningkatkan kinerja dari sistem instrumentasi alarm kebakaran di PRSG dan memudahkan operator dan petugas pengamanan dalam menemukan lokasi kejadian kebakaran di PRSG.

\section{DAFTAR PUSTAKA}

[1] Laporan Analisis Keselamatan (LAK) reaktor RSG-GAS Rev. 10.1.
[2] R. S. Rizki, S. I. Devi, M. Gapy, "Sistem Deteksi Kebakaran Pada Gedung Berbasis Programmable Logic Controller (PLC)". Banda Aceh: 2017.

[3] K. Ikhfan, "Pembangunan Sistem Monitoring Alarm Kebakaran Menggunakan Sensor Temperatur DHT11 Berbasis Microcontroller". Bandung: 2017.

[4] Badan Standardisasi Nasional, "SNI 03-1736-2000 Tata Cara Perencanaan Sistem Proteksi Pasif Untuk Pencegahan Bahaya Kebakaran Pada Bangunan Rumah dan Gedung". Jakarta: 2000.

[5] Siemens, "FC 726 Fire Control Panel". 2015.

[6] Siemens, "Cerberus Pro OOH740 Automatic Fire Detector". 2018.

[7] Osid Instrument, "Osid Smoke Detector Product Guide". 2016.

[8] Tyco, "Linier Heat Detection Cable". 2007.

[9] Badan Standardisasi Nasional, "SNI No. 03-3985-2000 Tata Cara Perencanaan, Pemasangan dan Pengujian Sistem Proteksi Pasif Untuk Pencegahan Bahaya Kebakaran Pada Bangunan Gedung". Jakarta: 2000. 